\title{
Rational use of mountain pasture land for eco- friendly livestock products in Central Caucasus
}

\author{
V.I. Ugorets ${ }^{1}$, I.E. Soldatova ${ }^{1}$, E.D. Soldatov ${ }^{1}$, S.W. Khairbekov ${ }^{1}$, O.K. \\ Gogaev $^{2^{*}}$
}

${ }^{1}$ North Caucasus Research Institute of Mining and Foothill Agriculture - a branch of the Federal State Budgetary Institution of Science of the Federal Scientific Center "Vladikavkaz Scientific Center of the Russian Academy of Sciences" 363110, RNO-Alania, Prigorodny district, Mikhailovskoye village, Williams Street, 1, Russia; 2Gorsky State Agrarian University, 362040, Republic of North Ossetia - Alania, Vladikavkaz, Kirov Street, 37, Russia ${ }^{*}$ Corresponding author e-mail: texmen2@mail.ru

Journal of Livestock Science (ISSN online 2277-6214) 12: 298-302

Received on 24/8/21; Accepted on 5/10/21; Published on 29/10/21

doi. 10.33259/JLivestSci.2021.298-302

\begin{abstract}
The article discusses the elements of technology for improving natural mountain pastures due to their biologization. It has been established that the introduction of biological fertilizers promotes an increase in the use of pasture fodder, an improvement in metabolic processes in the body of animals and has a positive effect on an increase in their productive qualities. The efficiency of the rational use of natural mountain pasture lands is one of the reserves for the growth of the production of ecologically clean livestock products in the territory of the Central Caucasus.
\end{abstract}

Key words: pasture; biological product; bioadditives; young cattle; blood; slaughter. 


\section{Introduction}

In accordance with the program of socio-economic development of the Republic of North Ossetia-Alania (RNO-Alania) until 2030, an urgent problem in the agro-industrial complex of the Republic is the creation of a solid forage base in the mountainous zone, with various methods of improving the use of mountain pastures and hayfields. Currently, more than $40 \%$ of the agricultural land area of the North Caucasian economic region is concentrated in the mountainous zone. At the same time, due to the prevailing historical traditions and a number of other reasons, mountain biogeocenosisare formed and function in complex (often extreme) geomorphological and soil-climatic conditions. All this represents more objectively, in comparison with ecosystems, resistance to external influences of biogeocenosis in case of violation of the regularity of a number of successive events. Therefore, the most acceptable and environmentally safe method of exploitation of agricultural land in the mountainous zone is grazing livestock and haymaking. Intensive grazing of cultivated pastures reduce feeding costs when compared to the traditional cut and carry system in farms with access to limited irrigation (López-González et al 2017). However, the technology for the production of pasture fodder is based on the unsystematic use of forage lands, which, in the absence of care for herbage, leads to a decrease in their productivity and, as a consequence, to their complete degradation, that is, to the development of erosion processes (Adinyaev et al., 2021).

One of the real ways to stop the degradation of pastures, increase soil fertility and increase the yield of agricultural and livestock products, is the development of environmentally friendly systems of grassland management. Organic matter mixture of humus, sheep manure, mineral-zeolite-containing agro-waste, combined with improved technology, rational use and comprehensive assessment of environmental consequences in the agricultural system, taking into account the consequences of the use of technologies on the productive qualities and physiological state of animals when carried to mountain pastures of the Dargav depression can be solution to the current and urgent ecological problem. (Gogaev et al, 2019; Djizibilov et al, 2019; Soldatov et al, 2020).

Relevance - Restoration of soil fertility in mountain forage lands, their rational use by farm animals in modern conditions and due to its ecological orientation, which has acquired particular relevance.

Purpose of the study - The aim of the study is to create target phytocenoses for various modes of their use on the basis of improving the composition of cereal and leguminous herbage in order to increase the efficiency of using biological nitrogen, soil fertility and environmental safety of crop and livestock products.

Scientific novelty - For the first time in the conditions of the North Caucasus, self-renewing target phytocenosis were created for various modes of use based on the improvement of cereal-legume herbage.

\section{Material and methods}

The research was carried out at the North Caucasus Research Institute of Mountain and Foothill Agriculture in the laboratory of mountain meadow farming and Animal Husbandry of the Federal State Budgetary Institution of Science Federal Research Center "Vladikavkaz Scientific Center of the Russian Academy of Sciences" Republic of North Ossetia-Alania, Mikhailovskoye village. Latitude: $43^{\circ} 05^{\prime} 58^{\prime \prime}$ s. w. Longitude: $44^{\circ} 37^{\prime} 53^{\prime \prime}$ w. d. Height above sea level: $605 \mathrm{~m}$. Experiments were carried out in the mountainous zone of the Dargav Basin (1640 meters above sea level) located in the second agroclimatic region, characterized by mountainous terrain, on aboriginal fattening cattle. For the experiment (using the method of pairs of analogs), two groups of bulls (6 heads in each) were worked out, taking into account live weight, physiological state, age, control and experimental groups, according to the methodology. The control group of animals used the natural background of pastures, the experimental group used green mass from the best variant of the experiment in the summer. In winter, hay collected from the same plots was used. All groups of animals were fed according to the standard norms (Vladimirov, 2008). Animal studies were carried out according to the generally accepted methods outlined in the guidelines (Amirov et al., 2020; Arilov et al., 2016; Komissarova et al., 2017; Stepanova, 2019; Katmakov et al., 2019; Korsun et al. 2015).

To assess the meat productivity, a control slaughter of steers was carried out in $(n=5)$ according to the method of VASHNIL, VIZ, VNIIMP (1965). The slaughter was carried out in the slaughter shop of LLC "Meat Gift". The scheme of feeding pastures is shown in Table 2.

\section{Results and Discussion}

The studies carried out earlier by our laboratory of mountain meadow cultivation and animal husbandry revealed that the introduction of biologically active preparations and local zeolite-containing preparations contributed to an increase in the yield of green mass of pasture grass stand on the experimental plot and its early vegetation (by 15-20 days) in spring and later wilting of grasses in autumn, which lengthened the grazing period to 180 days (until mid-October) Table 1 . As can be seen from the data in Table 1, the yield of the unfertilized pasture 
background was $59.0 \mathrm{c} /$ ha, while the yield from the fertilized pasture was four times higher and amounted to 298.8 c/ ha.

In our studies, we studied the accumulation of nutrients in the pasture herbage when used by gobies over the periods of the experiment, the data of which are presented in Table 2. Analyzing the results shown in Table 2, we can say that the best options for the use of pastures for the periods were 5 and 6 variants of the experiment, which contributed to the optimization of biological factors and led to an absolute and relative increase in the feed energy used directly for the formation of products, while reducing the total costs feed per unit of production (Ugorets et al, 2019; Ugorets et al. 2020).

The main indicator of the quality of pasture grass is their productive effect on animals. We have carried out a series of experiments on animals on the physiological parameters and productivity of fattening young cattle. In the age aspect, the dynamics of the live weight of the experimental fattening bulls is presented in Table 3 . According to table 3, the average daily gain in live weight of young animals in the experimental group, when using the grass of a biologized pasture, provided a more intensive growth of young animals in this group. In animals of the control group, the average daily gain was $0.888 \mathrm{~g}$ over the period of the experiment, in the experimental group, respectively 1.033. At the age of 12 months, the experimental group of animals exceeded the control animals in terms of the studied parameter by $20.72 \mathrm{~kg}(278.30 \pm 4.85$ versus $257.58 \pm 8.92)$. The animals of the control group were inferior to their counterparts from the experimental group by $8.04 \%$.

If the consumption of feed units per $\mathrm{kg}$ of live weight gain in the control group is $7.2 \mathrm{~kg} \mathrm{CFU}$, then in the experimental group it was $5.56 \%$ less and amounted to $6.8 \mathrm{~kg} \mathrm{CFU}$, which indicates a positive the effect on the body of animal feed of a biologized pasture. We retrospectively analyzed the results of the metabolic profile of the animals. The results of biochemical indicators were characterized by positive dynamics throughout the experiment in favor of the animals of the experimental group at all age periods, as evidenced by the data in Table 4 .

In our opinion, we explain this by the fact that the experimental group of animals grazed on a biologized pasture, which had a positive effect on their body and activated the hematopoietic organs better than when the control group of animals was grazed on a primitive pasture background. At the same time, in terms of protein content (on average for the pasture season), they were inferior by $3.00 \%$ ( $7.3 \mathrm{~g} \%$ versus $7.55 \mathrm{~g} \%$ ), in hemoglobin by $2.85 \%(10.16 \mathrm{~g} \%$ versus $10.45 \mathrm{~g} \%)$, in erythrocytes - $3.05 \%$ (6.21 versus 6.4 million in $1 \mathrm{~mm} 3)$. Humoral factors indicate the nonspecific resistance of their body by $2.85 \%$, which contributes to a more intensive course of metabolic processes in their body. And here it is also necessary to cancel the importance of the digestive process. Digestive and metabolic functions are concentrated in two open systems - the animal organism and the complex diversity of the world of microorganisms. Ruminants largely depend on the function of the rumen microflora to provide the required nutritional level. As a result of the vital activity of the cicatricial microflora, they are largely provided with energy sources, essential amino acids, carotene and completely B vitamins.

The grass of the biologized pasture had a beneficial effect on the cicatricial microflora of the experimental group of animals, as evidenced by the data in Table 5 .

By the number of ciliates, the gobies of the experimental group exceeded their control analogs by 18.76 thousand / $\mathrm{ml}$ ( $\mathrm{p}>0.95$ ) or $2.74 \%$, by the number of CLA - by 3.37 ( $>$ > 0.999), which confirms the provision of better digestibility of pasture feed by the gobies of the experimental group, and this affected on payment for forage products, table 6 Grass of biologized pasture had a beneficial effect on the cicatricial microflora of the experimental group of animals, as evidenced by the data in table 5 .

In order to assess the meat qualities of the fattened young stock at the time of fattening, a control slaughter of gobies was carried out. It was found that the gobies that were on the control were inferior to the analogs of the experimental group in terms of pre-slaughter weight by $11.10 \mathrm{~kg}$ or by $4.5 \%(\mathrm{p}>0.95)$, in terms of the weight of fresh carcasses by $14.15 \mathrm{~kg}$ or $9.94 \%$, in terms of internal fat by $0.8 \mathrm{~kg}$ or by $9.87 \%$, by slaughter weight by 14.95 $\mathrm{kg}$ or by $9.9 \%$ and by slaughter yield by $2.96 \%$, which affected the economic efficiency of livestock production in the mountains, table 7. The data in Table 7 show the positive effect of biologized mountain pastures, when used, on the productive qualities of the fattened young stock and profit from them for the season. Thus, 69575.00 rubles were received from the experimental group of animals, which is 5180.00 rubles or $8.04 \%$ more in comparison with the analogs of the control group.

\section{Conclusions}

Based on the research carried out, it can be concluded that the use of biological preparations, agricultural ore and sheep manure in mountain pasture and its use for fattening cattle contributes to the production of competitive, environmentally friendly high-quality livestock products with the maximum use of cheap feed. 
Table 1. Yield of high-mountain meadow pastures $(\mathrm{kg} / \mathrm{ha})$

\begin{tabular}{|l|l|l|l|l|l|l|l|}
\hline \multirow{2}{*}{ Index } & \multicolumn{3}{|l|}{ Harvest of green mass by terms of use (kg / ha) } & Pasture productivity / \\
\cline { 2 - 8 } & $30 \mathrm{~V}$ & 10 VI & 30 VI & 25 VII & 15 VIII & 15 XI & season (kg / ha) \\
\hline Fertilizer-free control & 8.5 & 10.2 & 11.5 & 12.6 & 9.1 & 7.5 & 59.0 \\
\hline Fertilized Pasture + Supplements & 27.8 & 43.0 & 65.6 & 69.8 & 53.5 & 39.1 & 298.8 \\
\hline
\end{tabular}

Table 2. Accumulation of nutrients in the pasture herbage and its use by bulls for fattening in different seasons

\begin{tabular}{|c|c|c|c|c|c|c|c|c|c|c|}
\hline \multirow{3}{*}{\begin{tabular}{|l|} 
Expt. \\
Groups
\end{tabular}} & \multirow[t]{3}{*}{ Fertilizer system } & \multicolumn{9}{|c|}{ The period of use of pastures by bulls } \\
\hline & & \multicolumn{3}{|c|}{ spring-summer } & \multicolumn{3}{|c|}{ summer } & \multicolumn{3}{|c|}{ autumn-winter } \\
\hline & & A & B & C & A & B & $\mathrm{C}$ & A & B & C \\
\hline 1 & Control (no fertilizer) & 1980 & 0.89 & 5.60 & 1789 & 0.75 & 6.60 & 1587 & 0.54 & 9.55 \\
\hline 2 & $\begin{array}{l}\text { Extrasol } 0.1+\text { agricultural ore } \\
1 \mathrm{t} / \mathrm{ha}\end{array}$ & 3393 & 1.53 & 3.30 & 3250 & 1.40 & 3.70 & 1789 & 0.61 & 8.19 \\
\hline 3 & $\begin{array}{l}\text { Extrasol } 0.1+\text { agricultural ore } \\
3 \mathrm{t} / \mathrm{ha}\end{array}$ & 4308 & 1.95 & 2.60 & 4180 & 1.72 & 2.90 & 1812 & 0.62 & 8.07 \\
\hline 4 & Extrasol $0.1+$ manure $10 \mathrm{t} / \mathrm{ha}$ & 5202 & 2.36 & 2.10 & 4855 & 2.03 & 2.50 & 2049 & 0.70 & 7.14 \\
\hline 5 & Extrasol $0.1+$ manure $30 \mathrm{t} / \mathrm{ha}$ & 5879 & 2.67 & 1.90 & 5555 & 2.32 & 2.20 & 2038 & 0.69 & 7.24 \\
\hline 6 & $\begin{array}{l}\text { Extrasol } 0.1+\text { agricultural ore } \\
1 \mathrm{t} / \mathrm{ha}+\text { manure } 10 \mathrm{t} / \mathrm{ha}\end{array}$ & 7213 & 3.27 & 1.50 & 6507 & 2.72 & 1.80 & 2041 & 0.69 & 7.24 \\
\hline
\end{tabular}

A- Collection of feed. Unit from 1 ha; B- Livestock load per hectare; C- Pasture required, ha

Table 3. Live weight and growth of male calves during summer, $\mathrm{kg}$.

\begin{tabular}{|l|l|l|}
\hline \multirow{2}{*}{$\begin{array}{l}\text { Age, } \\
\text { months }\end{array}$} & \multicolumn{2}{|c|}{ Group } \\
\cline { 2 - 3 } At birth & $24.80 \pm 1.05$ & $23.70 \pm 0.85$ \\
\hline 6 & $123.34 \pm 2.28$ & $122.90 \pm 1.92$ \\
\hline 9 & $177.80 \pm 2.71$ & $184.96 \pm 1.30$ \\
\hline 12 & $257.58 \pm 8.92$ & $278.30 \pm 4.85$ \\
\hline \multicolumn{3}{|c|}{ Average daily gain } \\
\hline 6 & 0.550 & 0.551 \\
\hline 9 & 0.605 & 0.693 \\
\hline 12 & 0.888 & 1.033 \\
\hline
\end{tabular}

Table 4. Biochemical parameters of the blood of bulls for the pasture period

\begin{tabular}{|c|c|c|c|c|c|}
\hline \multirow[t]{2}{*}{ Index } & \multirow{2}{*}{$\begin{array}{l}\text { Group of } \\
\text { animals }\end{array}$} & \multicolumn{3}{|c|}{ Age of bulls, months } & \multirow{2}{*}{$\begin{array}{l}\text { Average for the } \\
\text { grazing season }\end{array}$} \\
\hline & & 6 & 9 & 12 & \\
\hline \multirow{2}{*}{$\begin{array}{c}\text { Total protein } \\
\mathrm{g} / \%\end{array}$} & Control & $7.40 \pm 0.13$ & $6.78 \pm 0.07$ & $7.80 \pm 0.10$ & $7.33 \pm 0.29$ \\
\hline & Treatment & $7.52 \pm 0.10$ & $7.04 \pm 0.10$ & $8.10 \pm 0.10$ & $7.55 \pm 0.31$ \\
\hline \multirow{2}{*}{$\begin{array}{c}\text { Hemoglobin } \\
\text { g /\% }\end{array}$} & Control & $10.51 \pm 0.05$ & $9.46 \pm 0.23$ & $10.52 \pm 050$ & $10.46 \pm 0.35$ \\
\hline & Treatment & $10.60 \pm 0.04$ & $9.58 \pm 0.25$ & $11.17 \pm 0.78$ & $10.45 \pm 0.46$ \\
\hline \multirow{2}{*}{$\begin{array}{c}\text { Erythrocytes, } \\
\text { million in } 1 \mathrm{~mm} 3\end{array}$} & Control & $5.90 \pm 0.14$ & $6.90 \pm 0.09$ & $5.84 \pm 0.21$ & $6.21 \pm 0.34$ \\
\hline & Treatment & $6.04 \pm 011$ & $6.96 \pm 0.22$ & $6.20 \pm 0.10$ & $6.40 \pm 0.30$ \\
\hline \multirow{2}{*}{$\begin{array}{c}\text { Leukocytes, } \\
\text { thousand/ mm3 }\end{array}$} & Control & $7.30 \pm 0.11$ & $6.94 \pm 0.09$ & $7.20 \pm 0.11$ & $7.15 \pm 0.11$ \\
\hline & Treatment & $7.24 \pm 0.10$ & $6.98 \pm 0.04$ & $7.40 \pm 0.11$ & $7.21 \pm 0.12$ \\
\hline \multirow{2}{*}{$\begin{array}{l}\text { Reserve alkalinity, } \\
\mathrm{mg} \%\end{array}$} & Control & $446.40 \pm 13.81$ & $482.00 \pm 11.94$ & $461.60 \pm 15.20$ & $463.30 \pm 10.32$ \\
\hline & Treatment & $452.00 \pm 13.20$ & $491.60 \pm 9.50$ & $485.80 \pm 5.34$ & $476.50 \pm 12.35$ \\
\hline
\end{tabular}

Table 5. Indicators of cicatricial fluid in scars of bulls (on average for the pasture season)

\begin{tabular}{|l|l|l|}
\hline \multirow{2}{*}{ Index } & \multicolumn{2}{|c|}{ Group } \\
\cline { 2 - 3 } & Control & Treatment \\
\hline $\mathrm{pH}$ & $7.24 \pm 0.04$ & $7.33 \pm 0.05$ \\
\hline $\begin{array}{l}\text { Number of ciliates, } \\
\text { thousand in } 1 \mathrm{ml}\end{array}$ & $683.10 \pm 30.19$ & $701.86 \pm 35.31$ \\
\hline TsLA,\% & $21.36 \pm 1.86$ & $24.73 \pm 4.02$ \\
\hline
\end{tabular}


Table 6. Results of control slaughter of animals $(n=3)$

\begin{tabular}{|l|l|l|}
\hline \multirow{2}{*}{ Index } & \multicolumn{2}{c|}{ Group } \\
\cline { 2 - 3 } & Control & Treatment \\
\hline Pre-slaughter weight, $\mathrm{kg}$ & $267.63 \pm 11.35$ & $278.73 \pm 8.72$ \\
\hline Steam carcass weight, $\mathrm{kg}$ & $142.23 \pm 5.51$ & $156.38 \pm 6.62$ \\
\hline Internal fat mass, kg & $8.10 \pm 0.26$ & $8.90 \pm 0.13$ \\
\hline Slaughter weight, kg & $150.33 \pm 5.33$ & $165.28 \pm 6.52$ \\
\hline Lethal output,\% & 53.14 & 56.10 \\
\hline
\end{tabular}

Table 7. Economic efficiency of livestock production in the mountains in the summer.

\begin{tabular}{|l|l|l|}
\hline \multirow{2}{*}{\multicolumn{1}{|c|}{ Index }} & \multicolumn{2}{c|}{ Group } \\
\cline { 2 - 3 } & Control & Experienced \\
\hline Gain in live weight, kg & 257.58 & 278.30 \\
\hline Price for 1 kg of growth, rubles & 250.00 & 250.00 \\
\hline Total money received, rubles & 64395.0 & 69575.00 \\
\hline Profit received, rubles & - & 5180.00 \\
\hline
\end{tabular}

\section{References}

1) Adinyaev E.D., Abaev A.A., Tedeeva A.A., Mamiev D.M., Lagkueva E.A., Basiev S.S. 2021. Some issues of agriculture and meadow growing in mountainous areas and slope lands. Monograph.Vladikavkaz. - 256 p.

2) Amirov D.R., Tamimdarov B.F., Shageeva A.R. 2020. Clinical Hematology of Animals: Textbook. - Kazan: Information Technologies Center of the KSAVM. - 134p.

3) Arilov A.N., Marchenko V.V., ArilovYu.N. 2016. Technology of feeding farm animals. - Moscow: RGAUMoscow Agricultural Academy. - 212 p.

4) Djizibilov S., Gulueva L., Soldatov E., Soldatova I. 2019. Multifunctional unit and methods for improvement of mountain agricultural landscapes. In the collection: IOP Conference Series: Earth and Environmental Science. 12th International Scientific Conference on Agricultural Machinery Industry, INTERAGROMASH. -WITH. 012068.

5) Gogaev O.K., Ostaev G. Ya., Khosiev B.N., Kravchenko N.A., Kondratyev D.V., Nekrasova E.V. 2019. ZootechnicalAnd Management Accounting Factors Of Beef Cattle: Cost Optimization. Research Journal of Pharmaceutical, Biological and Chemical Sciences. Vol. 10.No 2.Pp. 221-231.

6) Katmakov P.S., Gavrilenko V.P., Bushov A.V. 2019. Biometrics.Textbook for universities. Moscow: Yurayt. $180 \mathrm{~s}$.

7) Komissarova T.N., Loginova T.P. 2017. Zootechnical analysis of feed. Study guide. - Nizhny Novgorod, FGBOU VO NGSKhA. $46 \mathrm{~s}$.

8) Korsun N.F., Markov A.S., Shafranskaya I.V. 2015. Methodology for Economic Research. Minsk: BGATU. $140 \mathrm{~s}$.

9) López-González F., Rosas-Dávila M., Celis-Alvarez M.D., Morales-Almaraz E., Domínguez-Vara I.A. and Arriaga-Jordán C.M. 2017. Milk production under grazing of different pasture grasses in small-scale dairy systems in the highlands of central Mexico. Journal of Livestock Science 8: 92-97

10) Soldatov E., Dzhibilov S., Soldatova I., Guluyeva L. 2020. Restoration of degraded mountain pastures of the Central Caucasus by targeted sowing of seeds of perennial grasses. E3S Web of Conferences. 13. Ser. "13th International Scientific and Practical Conference on State and Prospects for the Development of Agribusiness, INTERAGROMASH 2020" 2020, p. 09013.

11) StepanovaN.Yu. 2019. Fundamentals of scientific research Methodology of research work. St. Petersburg: SPbGAU. $-93 \mathrm{~s}$.

12) Ugorets V.I., Kairov V.R., Kebekov M.E., Gogaev O.K., Soldatova I.E., Soldatov E.D. 2019. Science-based use of mountain forage lands and their impact on the productive and biological peculiarities of fattening young cattle during the summer. Indo American Journal of Pharmaceutical Sciences. T. 6.No. 6.P. 12146-12152.

13) Ugorets V.I., Soldatova I.E., Soldatov E.D., Guluyeva L.R. 2020. Rational use of hayfields and pastures in the mountainous zone of North Ossetia-Alania.Bulletin of the Gorsky State Agrarian University. T. 57. No. 4. S. 91-97.

14) Vladimirov N.I., Cheremnyakova L.N., Lunitsyn V.G., Kosarev A.P., Polpelyaev A.S. 2008. Feeding farm animals.Tutorial. - Barnaul: Publishing house of AGAU. - 212 p. 